\title{
PENINGKATAN KETERAMPILAN SOSIAL MELALUI BERMAIN PLASTISIN
}

\author{
Khairul Huda \\ Program Studi Bimbingan dan Konseling, FIP IKIP Mataram \\ Email: khairulhuda@ikipmataram.ac.id
}

\begin{abstract}
The aims of this research is to get information and data about the effort to increase children's social skill in grade B kindergarten through playing of Plastisin, PAUD Merpati,Mataram. Research method used action research method. This method conduced in two cycles according to Kemmis and Taggart model which consist of 4 stages (plan, action, observation, and reflection). Data collecting techniques used field notes, interview, documentation, and observation. Sample was taken children of 5-6 years old. The result of the research shows that children's skill through playing of plastisin could increase of grade B kindergarten. Analysis of data obtained from the comparison between pre-action, and cycles two score. The end result of overall analysis of data is the percentage increase of 49.3\% which showed from pre-action the class average is 34.7 up to 84 at cycles two result.
\end{abstract}

Keywords: Social Skill, Playing of Plastisin

\begin{abstract}
Abstrak: Penelitian ini bertujuan untuk meningkatkan keterampilan sosial pada anak usia 5-6 tahun di PAUD Merpati, Mataram. Penelitian ini menggunakan metode penelitian tindakan kelas (action research) model Kemmis dan Taggart, yang meliputi empat tahapan, yaitu (1) perencanaan, (2) tindakan, (3) pengamatan, (4) refleksi. Dengan memberikan suatu tindakan pada subjek yang diteliti melalui bermain plastisin sebagai variabel bebas dan untuk mengetahui peningkatan keterampilan sosial anak sebagai variable terikat. Hasil penelitian menunjukkan adanya proses peningkatan hasil pada keterampilan sosial anak melalui bermain plastisin. Hal ini dapat dilihat mulai dari hasil pra-intervensi sampai dengan siklus II dimana keterampilan sosial yang dimiliki siswa kelas B secara keseluruhan meningkat dengan rerata 49.3\%.Hasil dari nilai rata-rata pra-.intervensi $34.7 \%$ dan meningkat sampai dengan $84 \%$ pada siklus II.
\end{abstract}

Kata Kunci: Ketermapilan Sosial, Bermain Plastisin

\section{LATAR BELAKANG}

Pendidikan anak usia dini adalah penting, mengingat bahwa anak berada pada masa yang disebut dengan "golden age", yaitu pada masa dimana anak tumbuh dan berkembang dengan cepat. Mengapa keterampilan sosial anak perlu dikembangkan adalah pada dasarnya setiap anak akan memerlukan bantuan orang lain dan akan hidup menjadi manusia sosial, namun dalam kenyataannya masih banyak anak yang tidak dapat bersosialisasi dengan orang lain dan lingkungan yang ada di sekitarnya. Anak belajar berinteraksi dengan lingkungan bahkan sejak dia berada di dalam kandungan ibunya. Selama dikandungan ibu, interaksi anak masih sangat terbatas. Setelah anak dilahirkan dimana interaksi-interaksi tersebut semakin menuju kepada kebutuhan sosial. Dari waktu ke waktu anak belajar dan dituntut untuk berlaku dan bertindak sesuai dengan kebutuhan sosial dimana ia berada.
Keterampilan sosial yang ditunjukkan anak merupakan cermin dari mampu dan tidaknya anak belajar untuk menjadi makhluk sosial.

Sebuah permasalahan yang menarik di kelompok B PAUD Merpati yang menjadi masalah dalam pendidikan anak usia dini yang dihadapi oleh sekolah tersebut, terutama pada keterampilan social anak. Peneliti merasa masih perluadanya usaha untuk meningkatkan keterampilan social pada anak karena berdasarkan pengamatan, peneliti menemukan beberapa anak diantaranya; (1) cenderung senang memilih bermain dengan sendirinya, (2) kurangnya sosialisasi dengan anak-anak lain, (3) anak sering mengganggu temannya, (4) sukar diatur dan membantah. Adapun alternative pemecahannya, peneliti memilih dengan menggunakan plastisin sebagai pengetahuan baru dalam pembelajaran keterampilan sosial bagi anak berdasarkan beberapa pertimbangan dan alasan diantaranya: 
1. Kegiatan bermain plastisin ini dilakukan dengan cara membentuk kelompok dan kerjasama yang baik pada anak.

2. Bermain plastisin ini menggunakan variasi yang berbeda dari masing-masing kelompok anak.

3. Bermain plastisin akan menyenagkan bagi anak karena ragam warna plastisin dan lilin yang digunakan untuk membuat kue ulang tahun pada setiap kelompok anak selalu berbeda.

4. Sudah menjadi anggung jawab bersama untuk membina dan mendidik anak-anak bangsa yang memiliki keterampilan sosial yang baik, sehingga siap diproyeksikan menjadi calon pemimpin dimasa mendatang.

\section{Keterampilan Sosial}

Menurut Muhibbin (2010: 120) keterampilan adalah belajar dengan menggunakan gerakan-gerakan motorik yakni berhubungan dengan urat-urat syaraf dan otot-otot/neuromuscular. Sedangkan sosial adalah belajar memahami masalahmasalah dan teknik-teknik untuk memecahkan masalah tersebut. Tujuannya untuk menguasai pemahaman dan kecakapan dalam memecahkan masalahmasalah sosial.

Sejalan dengan yang itu Janice J. Beaty(2014: 33) menyebutkan bahwa keterampilan sosial disebut juga prosocial behavior mencakup perilaku-prilaku seperti: (a) empati yang didalamnya anak-anak mengekspresikan rasa haru dengan memberikan perhatian kepada seseorang yang sedang tertekan karena suatu masalah dan mengungkapkan perasaan orang lain yang sedang mengalami konflik sebagai bentuk bahwa anak menyadari perasaan yang dialami orang lain, (b) kumurahan hati atau kedermawanan didalamnya anak-anak berbagi dan memberikan suatu barang miliknya kepada seseorang, (c) kerjasama yang didalamnya anak-anak mengmbil giliran atau bergantian dan menuruti perintah secara sukarela tanpa menimbulkan pertengkaran, dan (d) memberi bantuan yang didalamnya anak-anak membantu seseorang untuk melengkapi suatu tugas atau membantu temen-temennya yang membutuhkan.Sementara itu Chaplin (2014: 32)mengatakan bahwa keterampilan sosial merupakan bentuk perilaku, perbuatan dan sikap yang ditampilkan oleh individu ketika berinteraksi dengan orang lain disertai dengan ketepatan dan kecepatan sehingga memberikan kenyamanan bagi orang yang berada disekitarnya.

Wingkel (2010: 17)juga mendefinisikanketerampilan sosial adalah upaya menggunakan variasi dalam proses belajar mengajar, yang bertujuan mengatasi kebosanan siswa. Sejalan dengan itu, Hurlock (2013: 250) mengatakan bahwa keterampilan sosial adalah kemampuan untuk berperilaku yang sesuai dengan tuntunan sosial menjadi orang yang mampu bermasyarakat. Dari beberapa difinisi di atas dapat disintesiskan bahwa keterampilan sosial diartikan sebagai keterampilan individu disertai dengan kecakapan dan intilegent yang dimiliki anak dalam memulai aktivitas ataupun mempertahankan suatu hubungan yang positif dalam berinteraksi secara sosial.

Berdasarkan uraian di atas, maka perilaku sosial merupakan perilaku dimana seseorang harus berorientasi pada pencapaian suatu tujuan, nilai, dan penerimaan berdasarkan afeksi. Hal ini menunjukkan bahwa perilaku seseorang yang dipengaruhi oleh lingkungannya akan serta merta menanamkan konsep tertentu pada pemahaman dan dalam kesadarannya berperilaku sebagai mahluk sosial dalam lingkungannya.

\section{Pengertian Bermain}

Menurut Gordon \& Browne (2014: 66) bermain merupakan kegiatan yang memberikan kepuasan bagi diri sendiri.Para pakar juga mengatakan bahwa dunia anak adalah dunia bermain, bermain memiliki peran penting dalam mengembangkan segala aspek perkembangan anak.

Secara umum pengertian bermain adalah suatu kegiatan atau tingkah laku yang 
dilakukan anak secara sendirian atau berkelompok dengan menggunakan alat atau tidak untuk mencapai tujuan tertentu (Soegeng 2011: 199). Permainan kanakkanak adalah kesenian kanak-kanak, yang sesungguhnya amat sederhana bentuk dan isinya, namun memenuhi syarat-syarat ethis dan easthetis dengan semboyan: "dari nature kearah kultur"'(Ki Hajar Dewantara, 1977:256-267).

Lebih lanjut Morrison (2007: 283284) menjelaskan secara umum bermain merupakan:

The nation that children learn through play began with froebel, who built his system of schooling on the education value of play. Pieget believe that play promotes cognitive schemes and a mean by which children construct knowledge of their world. Vygotsky viewed the sosial intruction that occurs through play as essential children's develovemenet. He believe that children learn through sosial intruction with others the language and sosial skill.

Brewer (2013: 346) membagi bermain menjadi tiga tipe, yaitu; (1) bermain bebas, yaitu anak bebas memilih berbagai bentuk mainan dan juga bebas memainkan dengan caranya sendiri; (2) bermain dengan panduan, yaitu anak dapat memilih mainannya namun berdasarkan pilihan mainan/permainan yang sudah ditetapkan oleh guru sesuai dengan maksud untuk menanamkan konsep tertentu; (3) bermain dengan peraturan, yaitu guru memberikan arahan dan petunjuk kepada anak tentang bagaimana cara anak memainkan permainan tertentu.

Dari beberapa jenis bermain diatas maka dapat disimpulkan bahwa, bermain bagi anak dengan jenis atau metode apapun sangatlah memberikan nilai yang signifikan dan kontribusi positif pada setiap perkembangan aspek-aspek yang ada pada dalam diri anak.

\section{Bermain Plastisin}

Kegiatan bermain merupakan wadah dimana anak akan mencerminkan kemempuan intlektual, fisik, sosial dan emosionalnya. Melalui kegiatan bermain anak akan mendapatkan pengalaman yang banyak dan lebih luas, baik pengalaman terhadap diri sendiri, orang lain, maupun dengan lingkungan di sekitarnya. Ada berbagai macam variasi dalam permainan anak. Soetjiningsih (2013: 2) membagi variasi permainan menjadi 2, yaitu permainan aktif dan pasif. Dalam penelitian ini bermain plastisin adalah termasuk dalam permainan aktif, karena untuk menyelesaikan kegiatan bermain plastisin ini, anak akan mengekspresikan diri ke dalam kelompok bermain, berkolaborasi, berinteraksi, berpartisipasi secara aktif dengan teman-temannya.

\section{METODOLOGI PENELITIAN}

Penelitian ini menggunakan desain penelitian (action research). Penelitian tindakan Kemmis \& Mc Taggart (dalam Arikunto, 2006:132) ini meliputi empat tahap yaitu (1) perencanaan (planning), (2) tindakan (action), (3) pengamatan (observation), (4) refleksi (reflection). Pada model Kemmis \& Taggart tindakan (acting) dan observasi (observing) dijadikan sebagai satu kesatuan karena mereka menganggap bahwa kedua komponen tersebut merupakan dua kegiatan yang tidak bisa dipisahkan.

Teknik pengumpulan data yang digunakan dalam penelitian ini adalah catatan lapangan, wawancara, observasi dan lembar instrumen. Catatan lapangan digunakan untuk memperoleh sasaran yang diteliti yaitu tentang keterampilan sosial anak. Catatan lapangan dibuat dalam catatan yang lengkap setealah sekolah berakhir sehingga dapat didiskusikan bersama guru dan kepala sekolah dan direvisi guna penyempurnaan setelah peneliti sampai di ruamah, proses ini dilakukan setiap kali mengadakan pengamatan. Wawancara yang digunakan adalah wawancara terstruktur dan wawancara tidak terdtruktur dan merupakan wawancara terbuka. Wawancara dilakukan dengan kepala sekolah, guru, orang tua siswa, dan siswa untuk memperoleh informasi secara mendalam tentang hasil 
keterampilan sosial dan kegiatan bermain plastisin.

Observasi dilakukan dengan mendokumentasikan kegiatan dengan foto serta mencatat proses pembelajaran untuk mendapatkan data tentang aktivitas siswa dan guru selama kegiatan pembelajaran yang mengacu pada bermain plastisin. Lembar Instrumen yang telah disiapkan oleh peneliti berisikan indikator-indikator yang merupakan acuan dalam menilai keterampilan sosial siswa. Insrumen ini diisi oleh peneliti dan guru kelas dengan memberikan tanda check list $(\sqrt{ })$ pada setiap indikator sesuai dengan tingkatan keterampilan yang terlihat pada siswa.

Pengolahan data dalam penelitian ini menggunakan dua jenis data, sesuai dengan tuntutan penelitian tindakan, yaitu data kualitatif dan kuantitatif. Analisis data penelitian menggunakan analisis data kuantitatif dengan statistik deskriptif. Analisa data kuantitatif digunakan dengan cara membandingkan hasil yang diperoleh dari siklus pertama dan siklus kedua. Analisis data kualitatif dengan cara menganalisis data dari hasil catatan lapangan dan wawancara selama penelitian dengan langkah-langkah reduksi data, display data dan verifikasi data yang dilakukan dalam suatu proses.

\section{HASIL DAN PEMBAHASAN}

Dalam penelitian ini, peneliti mengukur peningkatan keterampilan sosial

\section{Siklus I}

Pemberian tindakan pada siklus I, maka peneliti dan kolaborator melakukan asesmen terhadap keterampilan sosial. Hal anak kemudian membandingkan hasil peningkatan antara sebelum dan sesudah diberikan tindakan. Observasi dilakukan selama pelaksanaan tindakan, dengan melakukan catatan, baik menggunakan catatan laangan, lembar obsevasi maupun instrument pemantau tindakan yang telah disediakan.

Fokus peningkatan keterampilan sosial anak dari penelitian ini dalam aspek kerjasama, meliputi (1) menolong/meminta pertolongan dari teman; aspek komunikasi, meliputi (1) menyampaikan pendapat/ide (2) mengajak teman untuk bermain bersama, dan (3) mau menjawab dan member pertanyaan; aspek berbagi, meliputi (1) mau berbagi mainan/makanan, dan aspek partisipasi, meliputi (1) bermain dalam kelompok, dan (2) bermain berdua/bertiga dengan teman, dan aspek adaptasi, meliputi (1) simpati; (2) empati; (3) disiplin.

Pelaksanaan pra-Intervensi untuk memperoleh data, dan dilakukan selama empat hari, untuk melihat, memperhatikan, dan meninjau sejauhmana perkembangan keterampilan sosial yang dimiliki anak paud Merpati dengan melakukan pengamatan serta mengisi instrument secara alami. Oleh sebab itu peneliti lebih banyak melakukan pengamatan pada saat anak bermain sendiri maupun kelompok, baik pada saat kegiatan berlangsung ataupun waktu jam istirahat. Setelah data diperoleh dan dianalisis, kemudian peneliti bersama kolaborator merencanakan tindakan siklus.

ini dilakukan untuk mengetahui skor yang diperoleh anak setelah pemberian tindakan pada siklus I. Hasil asesmen setelah pemberian tindakan pada siklus I adalah sebagai berikut:

Tabel 2. Keterampilan Sosial Anak Siklus I

\begin{tabular}{|c|c|c|c|}
\hline \multirow{2}{*}{ No. Responden } & \multicolumn{2}{|c|}{ Persentase } & \multirow{2}{*}{$\begin{array}{c}\text { Peningkatan } \\
\text { Persentase }\end{array}$} \\
\cline { 2 - 3 } & Pra-Siklus & Siklus I & $20.3 \%$ \\
\hline 1 & $41.6 \%$ & $62 \%$ & $21.2 \%$ \\
\hline 2 & $34.7 \%$ & $56 \%$ & $21.2 \%$ \\
\hline 3 & $27.7 \%$ & $49 \%$ & $18.6 \%$ \\
\hline 4 & $33.3 \%$ & $52 \%$ & $16.2 \%$ \\
\hline 5 & $34.7 \%$ & $51 \%$ & $22.8 \%$ \\
\hline 6 & $34.7 \%$ & $57 \%$ & $25.2 \%$ \\
\hline 7 & $34.7 \%$ & $60 \%$ & \\
\hline
\end{tabular}




\begin{tabular}{|c|c|c|c|}
\hline 8 & $38.8 \%$ & $59 \%$ & $20.1 \%$ \\
\hline 9 & $34.7 \%$ & $54 \%$ & $19.2 \%$ \\
\hline 10 & $33.3 \%$ & $54 \%$ & $20.6 \%$ \\
\hline 11 & $38.8 \%$ & $56 \%$ & $17.1 \%$ \\
\hline 12 & $27.7 \%$ & $48 \%$ & $20.2 \%$ \\
\hline 13 & $33.3 \%$ & $50 \%$ & $16.6 \%$ \\
\hline 14 & $34.7 \%$ & $50 \%$ & $15.2 \%$ \\
\hline 15 & $31.9 \%$ & $51 \%$ & $19.6 \%$ \\
\hline 16 & $33.3 \%$ & $51 \%$ & $17.6 \%$ \\
\hline 17 & $33.3 \%$ & $53 \%$ & $196 \%$ \\
\hline 18 & $43.6 \%$ & $62 \%$ & $18.4 \%$ \\
\hline Rata-rata & $\mathbf{3 4 . 7 \%}$ & $\mathbf{5 4 \%}$ & $\mathbf{1 9 . 4 \%}$ \\
\hline
\end{tabular}

Berdasarkan tabel diagram di atas, rata-rata keterampilan sosial anak belum mencapai indikator secara maksimal sesuai yang telah direncanakan oleh peneliti dan kolaborator. Anak-anak masih perlu mendapatkan bimbingan untuk mencapai indikator keterampilan sosial yang telah direncanakan. Adapun yang menjadi penyebabnya adalah; a) anak-anak masih harus beradaptasi dengan cara aturan main, karena bermain plastisin adalah permainan yang pertama yang diterapkan pada sekolah tersebut, b) intervensi baik dari guru maupun peneliti masih sering terjadi, c) masih ada siswa yang kurang berpartisipasi aktif dalam kelompok, d) siswa masih cenderung memilih kelompok dengan beberapa teman dekatnya. Diharapkan pada siklus II intervensi dapat lebih dikurangi, dan guru memeberikan arahan serta penguatan agar siswa mau berbaur dan saling berbagi dengan teman-temannya yang lain. Berdasarkan hal tersebut, maka peneliti memutuskan untuk melanjutkan ke siklus berikutnya. Hal ini dikarenakan peneliti dan kolaborator ingin seluruh anak mencapai semua indikator keterampilan sosial anak. Selain itu peneliti dan kolaborator ingin memantau persentase kenaikan yang signifikan, meskipun adanya peningkatan keterampilan sosial dengan rata-rata sebesar $19.4 \%$, namun kenaikan tersebut belum bisa dikatakan signifikan sesuai dengan persentase yang sudah ditetapkan yaitu sebesar $71 \%$.

\section{Siklus II}

Adapun hasil asesmen setelah pemberian tindakan pada siklus II adalah sebagai berikut

Table 3. Setatus Keterampilan Sosial Anak Siklus II.

\begin{tabular}{|c|c|c|c|c|}
\hline \multirow{2}{*}{ No. Responden } & \multicolumn{3}{|c|}{ Persentase } & \multirow{2}{*}{$\begin{array}{c}\text { Peningkatan } \\
\text { Persentase }\end{array}$} \\
\cline { 2 - 3 } & Pra Siklus & Siklus I & Siklus II & $27 \%$ \\
\hline 2 & $41.6 \%$ & $62 \%$ & $89 \%$ & $28 \%$ \\
\hline 3 & $34.7 \%$ & $56 \%$ & $84 \%$ & $30 \%$ \\
\hline 4 & $27.7 \%$ & $49 \%$ & $80 \%$ & $29 \%$ \\
\hline 5 & $33.3 \%$ & $52 \%$ & $81 \%$ & $35 \%$ \\
\hline 6 & $34.7 \%$ & $51 \%$ & $86 \%$ & $28 \%$ \\
\hline 7 & $34.7 \%$ & $57 \%$ & $85 \%$ & $24 \%$ \\
\hline 8 & $34.7 \%$ & $60 \%$ & $84 \%$ & $28 \%$ \\
\hline 9 & $38.8 \%$ & $59 \%$ & $87 \%$ & $27 \%$ \\
\hline
\end{tabular}




\begin{tabular}{|c|c|c|c|c|}
\hline 10 & $33.3 \%$ & $54 \%$ & $82 \%$ & $28 \%$ \\
\hline 11 & $38.8 \%$ & $56 \%$ & $80 \%$ & $24 \%$ \\
\hline 12 & $27.7 \%$ & $48 \%$ & $79 \%$ & $31 \%$ \\
\hline 13 & $33.3 \%$ & $50 \%$ & $85 \%$ & $35 \%$ \\
\hline 14 & $34.7 \%$ & $50 \%$ & $81 \%$ & $31 \%$ \\
\hline 15 & $31.9 \%$ & $51 \%$ & $80 \%$ & $29 \%$ \\
\hline 16 & $33.3 \%$ & $51 \%$ & $87 \%$ & $36 \%$ \\
\hline 17 & $33.3 \%$ & $53 \%$ & $85 \%$ & $32 \%$ \\
\hline 18 & $43.6 \%$ & $62 \%$ & $92 \%$ & $31 \%$ \\
\hline Rata-rata & $\mathbf{3 4 . 7 \%}$ & $\mathbf{5 4 \%}$ & $\mathbf{8 4 \%}$ & $\mathbf{2 9 . 5 \%} \%$ \\
\hline
\end{tabular}

Berdasarkan hasil analisis data pada siklus 1, persentase kenaikan diperoleh sebesar $19.4 \%$ dan pencapaian hasil $54 \%$, pada siklus II persentase kenaikan diperoleh sebesar $29.5 \%$ dan pencapaian hasil sebesar $84 \%$. Jadi persentase kenaikan seluruhnya dari pra siklus hingga siklus II sebesar
49.3\%. Hal ini memiliki makna bahwa telah terjadi peningkatan persentase yang signifikan dari keterampilan sosial anak pada pra penelitian hingga siklus II. Berikut adalah table grafik peningkatan keterampilan sosial anak secara keseluruhan.

Table 4. Analisis Peningkatan Keterampilan Sosial Pra Siklus, Siklus I, dan Siklus II

\begin{tabular}{|c|c|c|c|}
\hline Pra-siklus & Siklus 1 & Siklus 2 & Peningkatan \\
\hline $34.7 \%$ & $54 \%$ & $\mathbf{8 4 \%}$ & $49.3 \%$ \\
\hline
\end{tabular}

Analisis persentase kenaikan pra siklus ke siklus II dihitung dengan rumus: Persentase Siklus II - Persentase Pra-siklus

$=84 \%-34.7$

$=49.3 \%$

Histogaram 4. Grafik Peningkatan Keterampilan Sosial dari Pra siklus - Siklus 2

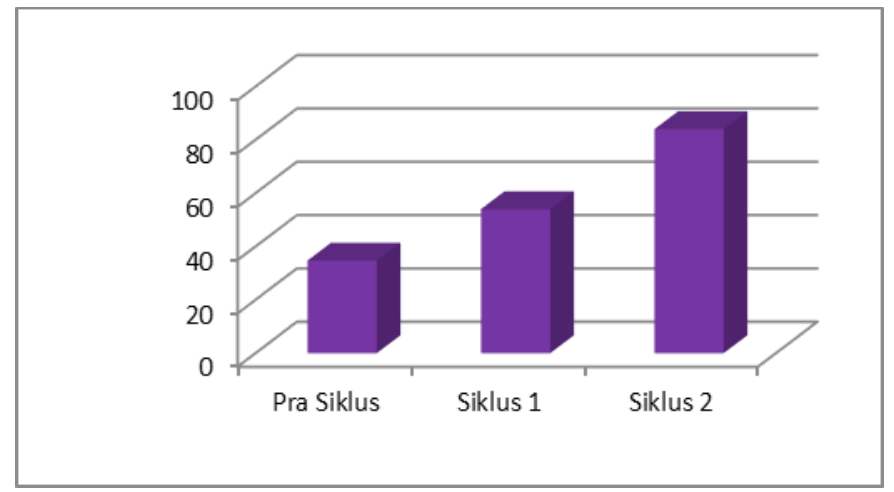


Per Aspek

Peningkatan keterampilan sosial anak di PAUD Merpati per aspek yang meliputi; kerjasama, komunikasi, berbagi, partisipasi dan adaptasi mulai dari pra siklus, siklus 1 dan siklus 2 dapat dilihat pada grafik beriku

\section{Histogaram 5. Grafik Peningkatan Keterampilan Sosial Per Aspek Dari Pra Siklus-}

Siklus 2

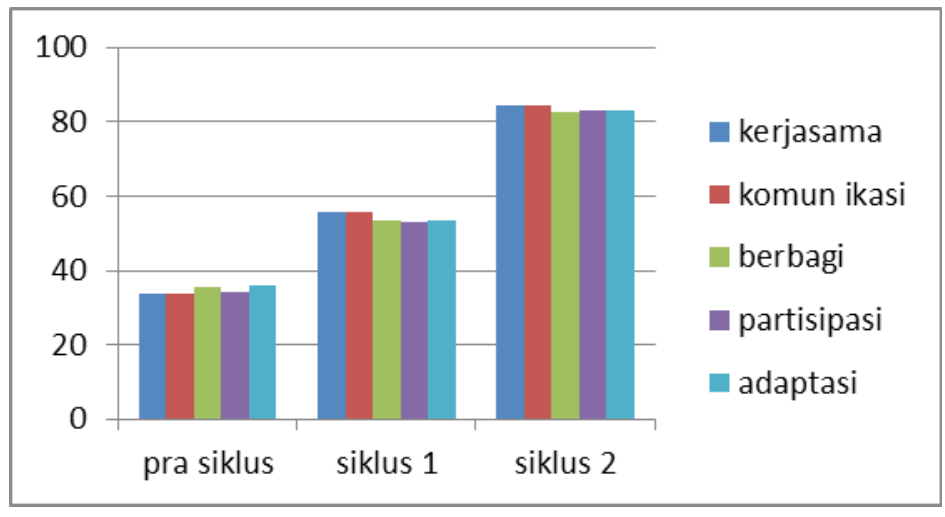

Berdasarkan grafik di atas, dapat dilihat terjadinya peningkatan pada setiap aspek terkait keterampilan sosial siswa, dengan persentase rata-rata peningkatan sebesar $50.52 \%$ dari persentase awal sebesar 33.68 menjadi $84.2 \%$, pada aspek kerjasama, untuk aspek komunikasi terjadi peningkatan sebesar $50.52 \%$ yang pada pra siklus 33.8 menjadi $84.32 \%$, sementara itu aspek berbagi mengalami peningkatan sebesar $47.22 \%$ dari persentase awal $35.42 \%$ menjadi $\quad 82.46 \%$, sedangkan aspek partisipasi terjadi peningkatan sebesar $48.64 \%$ dari persentase awal sebesar $34.17 \%$ manjadi $82.81 \%$, dan terakhir aspek adaptasi mengalami peningkatan sebesar $47.37 \%$ dari persentase awal sebesar $35.83 \%$ menjadi $83.2 \%$, setelah diberikan tindakan dalam dua siklus.

Hurlock (2012: 190) pola prilaku dalam situasi soasial pada masa kanakkanak, antara lain; (1) Kerja sama. Sejumlah kecil anak-anak belajar bermain atau bekerja secara bersama dengan anak lain sampai mereka berumur empat tahun semakin banyak kesempatan yang mereka miliki untuk melakukan sesuatu secara bersamasama, maka semakin cepet mereka belajar melakukannya dengan baik, (2) Persaingan. Jika persaingan merupakan dorongan bagi anak-anak untuk berusaha sebaik-baiknya, hal itu akan menambah sosialisasi mereka, (3) Kemurahan hati. Sebagaimana terlihat pada kesadaran untuk berbagi sesuatu dengan anak lain, meningkat dan sikap mementingkan diri sendiri semakin berkurang setelah anak belajar bahwa kemurahan hati menghasilkan penerimaan sosial, (4) Hasrat akan penerimaan sosial. Jika hasrat untuk diterima kuat, hal itu mendorong anak untuk menyesuaikan diri dengan tuntutan sosial. Hasrat untuk diterima oleh orang dewasa biasanya timbul lebih awal di bandingkan dengan hasrat untuk diterima oleh temen sebaya, (5) Simpati. Anak kecil tidak mampu berperilaku simpatik sampai mereka pernah mengalami situasi yang mirif dengan duka cita. Mereka mengekspresikan simpati dengan berusaha menolong atau menghibur seseorang yang sedang bersedih, (6) Empati. Empati kemampuan meletakkan diri sendiri dalam posisi orang lain dan menghayati pengalaman orang tersebut. Hal ini hanya berkembang jika anak dapat memahami ekspresi wajah atau maksud pembicaraan orang lain, (7) Ketergantungan. Ketergantungan terhadap orang lain dalam hal bantuan, perhatian, dan kasih sayang mendorong anak untuk berperilaku dalam cara yang diterima secara sosial. Anak yang berjiwa bebes kekurangan motivasi ini, (8) 
Sikap ramah. Anak kecil memperlihatkan sikap ramah melalui kesediaan melakukan sesuatu untuk atau bersama anak orang lain dan dengan mengekspresikan kasih sayang kepada mereka, (9) Sikap tidak mementingkan diri sendiri. Anak yang mempunyai kesempatan dan mendapat dorongan untuk membagi apa yang mereka miliki dan yang tidak terus menerus menjadi pusat perhatian keluarga, belajar memikirkan orang lain dan berbuat untuk orang lain dan bukan hanya memusatkan perhatian pada kepentingan dan milik mereka sendiri, (10) Meniru. Dengan meniru seseorang yang diterima baik oleh kelompok sosial, anak-anak mengembangkan sifat yang menambah penerimaan kelompok terhadap diri mereka, (11) Perilaku (attachment behavior). Dari landasan yang diletakkan pada masa bayi mengambangkan sesuatu kelekatan yang hangat dan penuh cinta kasih kepada ibu atau pengganti ibu, anak kecil mengalihkan pola perilaku ini kepada anak/orang lain dan belajar membina persahabatan dengan mereka.

\section{KESIMPULAN}

Berdasarkan hasil analisis data pembahasan pada penelitian yang berjudul Peningkatan Keterampilan Sosial Anak melalui Bermain plastisin dapat diambil kesimpulan sebagai berikut:

1. Proses pelaksanaan bermain plastisin dengan menggunakan ragam warna untuk membentuk kue ulang tahun dan lilin dapat meningkatkan keterampilan sosial anak terdiri dari beberapa tahapan yaitu perencanaan, pelaksanaan dan evaluasi, perencanaan terkait dengan pemilihan tema dan media yang digunakan, kemudian pelaksanaan dan evaluasi untuk mengetahui sejauh mana tingkat keberhasilan keterampilan sosial anak.

2. Keterampilan sosial anak dapat ditingkatkan melaui bermain plastisin dengan menggunakan ragam warna bentuk kue ulang tahun dan lilin serta langkah yang berbada pula, bermain plastisin dapat dilihat dari peningkatan skor pada Pra Penelitian didapat persentase sebesar $34.7 \%$, sedangkan pada siklus I didapat persentase sebesar 54\%. Dari data tersebut dapat dikatakan bahwa persentase mengalami peningkatan pada indikator secara keseluruhan sebesar 19.4\%. Hasil siklus II diperoleh persentase sebesar $84 \%$ sehingga terjadi peningkatan sebesar $29.5 \%$ secara keseluruhan dari pra intervensi-siklus II meningkat hingga 49.3\%. Hal tersebut menunjukkan bahwa persentase kenaikan peningkatan keterampilan sosial anak dapat dikatakan signifikan karena terus meningkat. Dengan demikian, maka dapat dinyatakan bahwa melalui bermain plastisin dapat meningkatkan keterampilan sosial anak usia 5-6 tahun.

\section{DAFTAR PUSTAKA}

Amalina dkk. "Permainan Sosiodrama Terhadap Stimulasi Perkembangan Emosi Anak Usia Prasekolah"nisadewanti@gmail.com.

Elizaberd. Hourlock, Perkembangan Anak, Jakarta, PT. Glora Aksara Pratama, 2013.

George S. Morisson, Dasar-Dasar Pendidikan Anak Usia Dini, Jakarta, PT indeks, 2012.

Hamzah, Orientasi Baru Dalam Psikologi Pembelajaran. PT. Bumi Aksara, Jakarta, 2010.

Ki Hajar Dewantara, Majlis Luhur Persatuan Taman Siswa Yogyakarta, 1977.

Morrison, Dasar-Dasar Pendidikan Anak Usia Dini, PT. Indeks, Jakarta, 2008.

Muhibbin, Psikologi Pendidikan, Bandung, Pt. Remaja Rosdakarya, 2010.

Ratna Pangastuti, Edutaintment Pendidikan Anak Usia Dini, Yogyakarta, Pustaka PeLajar 2014.

Susanto, Perkembangan Anak Usia Dini, Jakarta, Prenada Media Group, 2011.

Siska, Penerapan Metode Bermain Peran (Role Playing) Dalam Meningkatkan Keterampilan Sosial, $\underline{\text { http://jurnal.upi.edu/8705, }}$ diakses 06 November 2014.

Perdani, "peningkatan Keterampilan Sosial Anak Melalui Permainan Tradisional”. Jurnal Pendidikan Usia Dini, Vol. 8 Jakarta, 2014.

Soegeng,S.Konsep Pendidikan Anak Usia Dini, jakrta, 2011. 